\title{
KETAHANAN BERSEKOLAH PENDUDUK USIA 7-18 TAHUN DI PROVINSI JAWA TENGAH TAHUN 2017
}

\author{
(RESILIENCE TO SCHOOL POPULATION AGED 7-18 YEARS \\ IN THE CENTRAL JAVA PROVINCE IN 2017)
}

\author{
Boy Ampristi ${ }^{1}$, Yaya Setiadi ${ }^{2}$ \\ Politeknik Statistika STIS ${ }^{1}$ \\ Politeknik Statistika STIS ${ }^{2}$ \\ Jatinegara, Jakarta Timur \\ E-mail: 15.8542@stis.ac.id
}

\begin{abstract}
ABSTRAK
Pendidikan memegang peranan penting dalam kehidupan berbangsa dan bernegara, terutamanya dalam pengembangan Sumber Daya Manusia yang berkualitas. Pendidikan diperlukan untuk mendorong percepatan pembangunan nasional serta pembangunan daerah yang bertujuan untuk meningkatkan kesejahteraan rakyat dan mencerdaskan kehidupan bangsa. Selain itu pendidikan merupakan salah satu tujuan dari Sustanaible Development Goals (SDGs) pada tujuan keempat. Pemerintah sudah mengupayakan perbaikan pendidikan melalui berbagi program, salah satunya program wajib belajar. Namun belum sepenuhnya mengatasi permasalahan dalam bidang pendidiakan. Salah satu daerah yang mengalami permasalahan tersebut adalah Provinsi Jawa Tengah. Hal ini digambarkan dari angka putus sekolah tertinggi diwilayah barat Indonesia, ratarata lama sekolah terendah di wilayah barat Indonesia dan terendah ke lima secara nasional, banyaknya penduduk yang hanya menamatkan pendidikan dasar dan menurunya tingkat partisipasi sekolah. Selain itu, terdapat kesenjangan pendidikan antara daerah perdesaan dan perkotaan. Penelitian ini menggunakan metode analisis ketahanan hidup distribusi Gompertz untuk mengetahui faktor-faktor yang mempengaruhi ketahanan bersekolah penduduk daerah perdesaan dan perkotaan usia 7-18 tahun di Provinsi Jawa Tengah tahun 2017. Berdasarkan hasil penelitian, untuk daerah perdesaan terdapat lima variabel bebas yang signifikan, yakni: bantuan KIP, pendidikan KRT, lapangan usaha KRT, status kemiskinan dan status orangtua. Sementara itu, untuk daerah perkotaan terdapat tiga variabel bebas yang signifikan, yakni: pendidikan KRT, status kemiskinan dan status orangtua.
\end{abstract}

Kata kunci: Analisis Ketahanan Hidup, Ketahanan Bersekolah, Status Wilayah Tempat Tinggal, Gompertz

\begin{abstract}
Education has an important role in the life of the nation and state, especially in the development of human resources' quality. Education is needed to encourage the acceleration of national and regional development which aims to improve people's welfare and education. In addition, education is one of the objectives of the Sustanaible Development Goals (SDGs) in the fourth goal. The government has tried to improve education through many programs, one of them is compulsory education. However, it has not completely overcome the problems in the education field. One of region that experienced these problems is Central Java Province. It is illustrated by the highest dropout rate in the western part of Indonesia, the lowest average length of school in the western part of Indonesia and the fifth lowest nationally, the number of people who only complete basic education and the decrease in school participation rates. In addition, there is educational gap between rural and urban areas. This study uses the survival analysis method with Gompertz distribution to determine the factors that influence the resilience school in rural and urban areas aged 7-18 years in Central Java Province in 2017. Based on the results of the study, or rural areas there are five significant independent variables, namely: KIP assistance, KRT education, KRT business field, poverty status and parental status. Meanwhile, for urban areas there are three significant independent variables, namely: household education, poverty status and parental status.
\end{abstract}

Keywords: Survival Analysis, Drop Out, Status of Residence, Gompertz 


\section{PENDAHULUAN}

Pendidikan memegang peranan penting dalam kehidupan berbangsa dan bernegara, terutamanya dalam pengembangan Sumber Daya Manusia (SDM) yang berkualitas. Pendidikan diperlukan untuk mendorong percepatan pembangunan nasional serta pembangunan daerah yang bertujuan untuk meningkatkan kesejahteraan rakyat dan mencerdaskan kehidupan bangsa, sebagaimana yang tercantum dalam UUD 1945 alinea ke empat, yang merupakan cita-cita luhur pendiri bangsa Indonesia. Pendidikan juga merupakan hak bagi setiap warga negara Indonesia sebagaimana yang tercantum dalam UUD 1945 Pasal 31 ayat 1 , serta merupakan salah satu tujuan dari Sustanaible Development Goals (SDG's) pada tujuan keempat yakni "memastikan pendidikan yang inklusif dan berkualitas setara, juga mendukung kesempatan belajar seumur hidup bagi semua".

Melihat pentingnya peran pendidikan sehingga mendorong pemerintah untuk terus memperhatikan dan mengupayakan perbaikan di bidang pendidikan melalui berbagai program. Program pemerintah mengenai pendidikan tercantum pada nawacita tujuan ke lima "Meningkatkan kualitas hidup manusia Indonesia melalui peningkatan kualitas pendidikan dan pelatihan dengan Program Indonesia Pintar", hal tersebut juga tercantum dalam Rencana Pembangunan Jangka Menengah Nasional (RPJMN) 2015-2019 yaitu meningkatkan kualitas hidup manusia dan masyarakat Indonesia dengan membangun pendidikan melalui pelaksanaan PIP. Pendidikan di Indonesia juga sudah diatur dalam Undang-undang Nomor 20 Tahun 2003 tentang Sistem Pendidikan Nasional yang mengamanatkan bahwa setiap warga negara yang berusia 7-15 tahun wajib mengikuti pendidikan dasar, serta program wajib belajar juga tercantum dalam Peraturan Pemerintah (PP) Nomor 47 Tahun 2008 tentang wajib belajar yang menyatakan bahwa pemerintah pusat dan pemerintah daerah bertanggungjawab untuk memberikan pendidikan minimal bagi warga negara Indonesia untuk dapat mengembangkan potensi dirinya agar dapat hidup mandiri di dalam masyarakat atau melanjutkan pendidikan ke jenjang yang lebih tinggi.

Penduduk Indonesia belum sepenuhnya mampu menyelesaikan pendidikan dasar sembilan tahun dan melanjutkan ke pendidikan dua belas. Salah satu daerah yang mengalami permasalahan tersebut adalah Provinsi Jawa Tengah. Secara geografis, Provinsi Jawa Tengah terletak di wilayah barat Indonesia tepatnya pulau jawa yang mana dari segi fasilitas dan akses terhadap pendidikan lebih baik dari wilayah lainya. Hal ini terlihat dari beberapa fasilitas penunjang pendidikan yang sudah memadai seperti jumlah sekolah, ruang kelas yang sudah memenuhi standar ideal, dan tenaga pendidik yang sudah memenuhi kualifikasi. Namun hal tersebut berbanding terbalik dengan target menuntaskan pendidikan dasar sembilan tahun kemudian melanjutkan ke pendidikan dua belas tahun. Berdasarkan publikasi BPS dalam potret pendidikan Indonesia statistik pendidikan 2017, menyatakan bahwa Provinsi Jawa Tengah merupakan provinsi dengan angka putus sekolah tertinggi diwilayah barat Indonesia yakni sebesar 1,51 dan angka tersebut lebih tinggi dari pada rata-rata nasional sebesar 1,17. Hal ini terlihat pada Gambar 1.

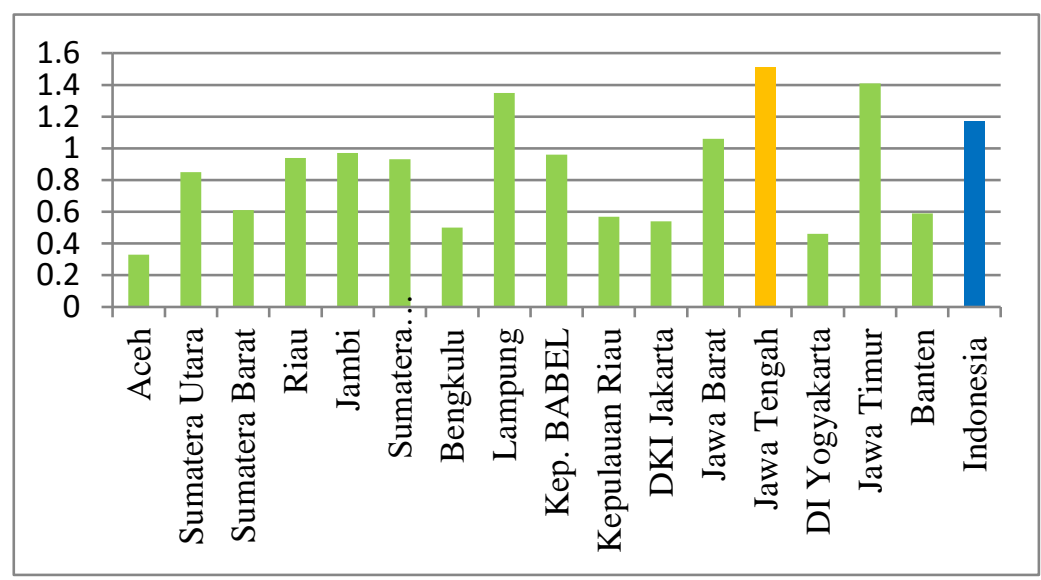

Sumber: Statistik Pendidikan Tahun 2017, BPS

Gambar 1. Angka Putus Sekolah di wilayah barat Indonesia tahun 2017 
Angka putus sekolah di Provinsi Jawa Tengah semakin meningkat dengan bertambahnya jenjang pendidikan, pada jenjang pendidikan SMP/sederajat angka putus sekolah di Provinsi Jawa Tengah sebesar 1,85 lebih tinggi dari nasional 1,76. dan pada jenjang pendidikan SMA/sederajat di Provinsi Jawa Tengah sebesar 4,78 lebih tinggi dari pada angka putus sekolah secara nasional sebesar 3,35.

Sejalan dengan angka putus sekolah, angka rata-rata lama sekolah di Provinsi Jawa Tengah merupakan angka rata-rata lama sekolah terendah di wilayah barat Indoensia dan terendah ke lima secara nasional yakni hanya sebesar 7,77 yaitu berada dibawah rata-rata nasional. Berdasarkan publikasi BPS dalam Statistik Pendidikan Jawa Tengah tahun 2017, Angka Partisipasi Sekolah (APS) usia 7-12 tahun 99,62 persen, APS usia 13-15 tahun 95,48 persen, APS usia 16-18 68,48 persen. Hal ini menunjukan semakin tinggi usia sekolah, tingkat partisipasi semakin rendah dan penduduk yang tidak bersekolah lagi semakin bertambah, dimana pada jenjang pendidikan SMP (13-15 tahun) terdapat 4,1 persen yang tidak bersekolah lagi, serta pada jenjang pendidikan SMA/sederajat (usia 16-18 tahun) terdapat 31,04 persen penduduk yang tidak bersekolah lagi. Permasalah tersebut diperkuat dengan sebanyak 53,65 persen penduduk usia 15 tahun ke atas di Jawa Tengah yang hanya menamatkan SD/MI kebawah.

Selain permasalahan tersebut, permasalahan lain yang dihadapi Provinsi Jawa Tengah dalam bidang pendidikan adalah kesempatan memperoleh pendidikan yang belum merata antara daerah perdesaan dan perkotaan. Menurut BPS "di Provinsi Jawa Tengah kesempatan penduduk di daerah perkotaan untuk menikmati pendidikan lebih besar daripada penduduk yang di daerah perdesaan". Hal ini dikarenakan terdapat kesenjangan partisipasi sekolah antara daerah perkotaan dan perdesaan. Sejalan dengan partisipasi sekolah, persentase anak yang tidak bersekolah lagi di daerah perdesaan lebih besar dibandingkan daerah perkotaan terutama pada jenjang pendidikan SMP dan SMA. Kesenjangan pendidikan antara daerah perdesaan dan perkotaan juga terlihat dari perbedaan nilai rata-rata lama sekolah, didaearah perkotaan sebesar 8,68 dan daerah perdesaan hanya sebesar 6,88 . Beberapa penelitian juga menenemukan bahwa terdapat perbedaan memperoleh pendidikan antara daerah perkotaan dan perdesaan, salah satunya penilitian yang dilakukan oleh Jones dkk (1999) menemukan bahwa partisipasi sekolah di daerah pedesaan lebih rendah daripada di daerah perkotaan karena adanya ketidaksamaan anatara wilayah kota dan desa dalam hal ketersedian/kelengkapan fasilitas pendidikan.

Berdasarkan uraian diatas, untuk melihat ketahanan bersekolah penduduk daerah perdesaan dan perkotaan usia 7-18 tahun Provinsi Jawa Tengah serta faktor-faktor yang mempengaruhinya. Metode yang digunakan dalam penelitian ini adalah Analisis ketahanan hidup (survival analysis).

\section{METODE}

Data yang digunakan dalam penelitian ini adalah data sekunder dari hasil Survei Sosial Ekonomi Nasional (Susenas) Kor Maret tahun 2017. Susenas Maret 2017 merupakan salah satu survei rutin BPS yang menyediakan data pembangunan di bidang sosial ekonomi pada tingkat nasional, provinsi, dan kabupaten/kota. Susenas mengumpulakn data Kor dan data modul. Pendataan Susenas Maret 2017 mencakup 300.000 rumah tangga.

Unit analisis yang digunakan dalam penelitian ini adalah penduduk usia 7-18 tahun yang berstatus pernah sekolah (masih sekolah dan tidak bersekolah lagi) di jenjang pendidikan formal SD/sederajat sampai jenjang pendidikan SMA/sederajat yang termasuk dalam sampel Susenas kor tahun 2017. Yang mana terdapat 17.085 penduduk usia 7-18 tahun di Provinsi Jawa Tengah yang dianalisis dalam penelitian ini.

Metode yang digunakan dalam penelitian ini yaitu analisis deskriptif dan analisis inferensia. Analisis deskriptif menggunakan diagram, tabel dan kurva kaplan meier, sedangkan Analisis inferensia yang digunakan dalam penelitian ini adalah analisis ketahanan hidup (survival analysis). Penelitian ini menggunakan survival analysis model Proportinal Hazard (PH) dengan survival time ( $\mathrm{T}$ ) adalah lama bersekolah (tahun) penduduk usia 7-18 tahun dan censorship status ( $\delta$ ): Event (putus sekolah), sensor (tidak putus sekolah/masih bersekolah/tamat SMA(sederajat)). Adapun tahapan analisis yang digunakan dalam penelitian ini adalah sebagai berikut: 
a. Pengujian Asumsi Proportinal Hazard (PH) dengan metode goodnes of fit test

b. Pemilihan Model Terbaik, Semiparametrik (Cox PH) dan parametrik (eksponensial, gompertz, dan weibull) berdasarkan nilai Akaike Information Criterion (AIC) terkecil.

c. Pembentukan Model dengan backward elimination

d. Pengujian model terbaik dengan melakukan uji simultan serta uji parsial.

\section{HASIL DAN PEMBAHASAN}

\section{Analisis Deskriptif}

Berdasarkan hasil pengolahan data Susenas Kor Provinsi Jawa Tengah tahun 2017, total penduduk usia 7-18 tahun yang tercakup dalam penelitian ini adalah sebanyak 17.085 penduduk. Penduduk usia 7-18 tahun yang tinggal di wilayah perdesaan adalah sebanyak 9.248 (54,13 persen), sedangkan penduduk usia 7-18 tahun yang tinggal di wilayah perkotaan adalah sebanyak 7.837 (45,87 persen). Penduduk usia 7-18 tahun di Provinsi Jawa Tengah yang mengalami putus sekolah berdasarkan data Susenas Kor maret 2017 adalah sebanyak 1.277 (7,47 persen). Di daerah perdesaan terdapat 573 (6,20 persen) penduduk yang mengalami putus sekolah (event) dan 8.675 (93,80 persen) yang tidak putus sekolah (sensor). Sementara itu, di daraeh perkotaan terdapat 704 (8,98 persen) penduduk yang mengalami putus sekolah (event) dan 7.133 ( 91,02 persen) yang tidak putus sekolah (sensor). Berikut merupakan karakteristik penduduk daerah perdesaan dan perkotaan usia 7-18 Tahun di Provinsi Jawa Tengah berdasarkan variabel-variabel bebas yang digunakan:

Tabel 1. Karakteristik penduduk putus sekolah daerah perdesaan dan perkotaan usia 7-18 tahun di Provinsi Jawa Tengah tahun 2017.

\begin{tabular}{|c|c|c|c|}
\hline \multirow{2}{*}{ Variabel } & \multirow{2}{*}{ Kategori } & \multicolumn{2}{|c|}{ Klasifikasi Wilayah Tempat Tinggal } \\
\hline & & Perdesaan (\%) & Perkotaan (\%) \\
\hline (1) & (2) & (3) & (4) \\
\hline \multirow[t]{2}{*}{ Jenis Kelamin } & Laki-laki & 6,64 & 9,25 \\
\hline & Perempuan & 5,75 & 8,70 \\
\hline \multirow[t]{2}{*}{ Bantuan KIP } & Menerima & 2,72 & 3,81 \\
\hline & Tidak Menerima & 7,06 & 10,68 \\
\hline \multirow[t]{2}{*}{ Jenis Kelamin KRT } & Laki-laki & 6,09 & 8,67 \\
\hline & Perempuan & 7,47 & 13,35 \\
\hline \multirow{2}{*}{ Jumlah ART } & $<=4$ & 5,10 & 8,32 \\
\hline & $>4$ & 7,60 & 10,06 \\
\hline \multirow[t]{3}{*}{ Pendidikan KRT } & Tinggi & 1,65 & 1,89 \\
\hline & Menengah & 3,20 & 3,80 \\
\hline & Dasar & 8,59 & 10,09 \\
\hline \multirow[t]{2}{*}{ Lapangan Usaha KRT } & Non-pertanian & 5,70 & 8,36 \\
\hline & Pertanian & 9,65 & 9,83 \\
\hline \multirow[t]{2}{*}{ Status Kemiskinan } & Tidak Miskin & 5,98 & 8,41 \\
\hline & Miskin & 7,98 & 12,63 \\
\hline \multirow[t]{2}{*}{ Status Orangtua } & Lengkap & 5,91 & 8,50 \\
\hline & Tunggal & 9,50 & 14,89 \\
\hline
\end{tabular}

Sumber: Susenas 2017, diolah

Berdasarkan Tabel 1, terlihat bahwa untuk daerah perdesaan dan perkotaan persentase penduduk usia 7-18 tahun yang mengalami putus sekolah lebih banyak pada penduduk yang berjenis kelamin laki-laki, tidak menerima bantuan KIP, jenis kelamin KRT perempuan, jumlah anggota rumah tangga lebih dari 4, tingkat pendidikan KRT hanya sampai pendidikan dasar, lapangan usaha KRT di bidang pertanian, status kemiskinan miskin dan status orangtua tunggal. Persentase putus sekolah tertinggi di daerah pedesaan terjadi pada penduduk dengan KRT yang bekerja dibidang pertanian dan di perkotaan terjadi pada penduduk yang tinggal bersama orangtua tunggal. Persentase putus sekolah terendah didaerah pedesaan maupun perkotaan adalah pada pendidikan 624 
kepala rumah tangga dengan tingkat pendidikan tinggi. Fenomena tersebut dikarenakan pada keluarga dengan pendapatan tinggi dan tingkat pendidikan orangtua yang semakin tinggi, dapat menurunkan kemungkinan untuk putus sekolah (Song, dkk 2012).

Berdasarkan gambar 2, Ketahanan bersekolah antara daerah perdesaan dan perkotaan menurun seiring dengan bertambahnya waktu sekolah. Namun, secara keseluruhan ketahanan bersekolah penduduk yang tinggal di daerah perdesaan lebih baik dari pada yang tinggal di daerah perkotaan. Hal ini berbanding terbalik dengan temuan Jones, dkk (1999) dan sudarwati (2009), bahwa putus sekolah cenderung terjadi di daerah perdesaan. Fenomena bisa dikaitkan dengan, di Provinsi Jawa Tengah terutama di daerah perkotaan banyak anak yang bersekolah sambil bekerja, hal ini berdasarkan publikasi BPS dalam profil anak Indonesia, yang mana 45 persen penduduk usia 7-17 tahun yang bekerja berstatus masih sekolah, serta di daerah perkotaan penerima bantuan KIP lebih sedikit dibandingkan dengan daerah perdesaan.

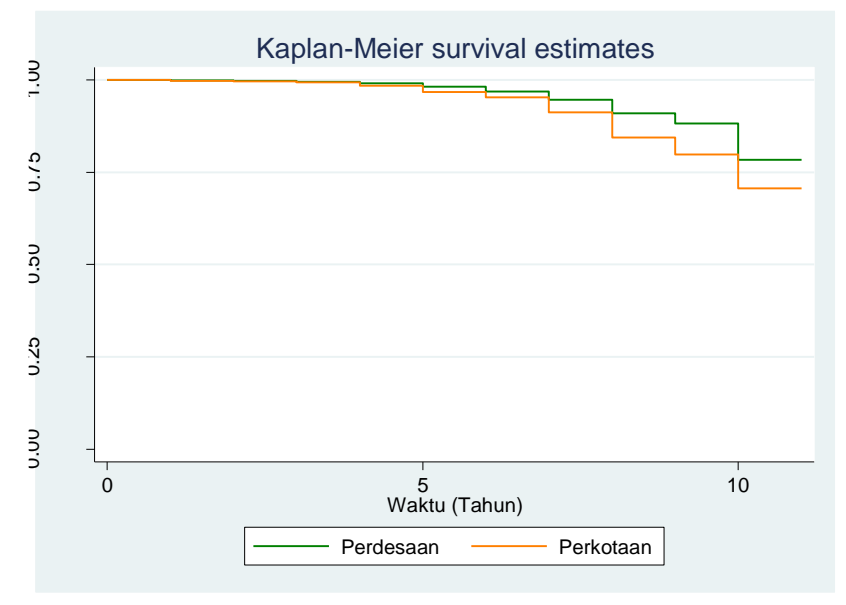

Sumber: Susenas 2017, diolah

Gambar 2. Kurva Kaplan Meier berdasarkan wilayah tempat tinggal

\section{Analisis Inferensia}

\section{Pengujian Asumsi Proportional Hazard(PH)}

Asumsi PH adalah asumsi yang menyatakn bahwa hazard ratio tidak bergantung pada waktu (t), sehingga konstan dari waktu ke waktu. Pengujian asumsi PH dapat dilakukan dengan beberapa metode, namun dalam penelitian ini menggunakan metode goodness of fit test. Asumsi PH terpenuhi ketika $p$-value $>$ a $(0,05)$. Berdasarkan hasil pengujian asumsi $\mathrm{PH}$, untuk daerah perdesaan terdapat dua variabel yang tidak memenuhi asumsi $\mathrm{PH}$, yakni: jenis kelamin dan jumlah anggota rumah tangga. Sedangkan untuk daerah perkotaan terdapat dua variabel yang tidak memenuhi asumsi $\mathrm{PH}$, yakni: jenis kelamin dan bantuan KIP. Variabel yang tidak memenuhi asumsi PH tidak dikutsertakan dalam pemodelan.

\section{Pemilihan Model Terbaik}

Langkah selanjutnya adalah pemilihan model terbaik antara model semiparametrik (Cox PH) dan parametrik (Eksponensial, Gompertz dan Weibull). Pemilihan model terbaik dilakukan dengan membandingkan nilai Akaike's Information Criterion (AIC). Nilai AIC dari masing-masing model dapat dilihat pada tabel berikut: 
Tabel 2. Nilai AIC masing-masing model berdasarkan daerah perdesaan dan perkotaan

\begin{tabular}{|c|c|c|c|}
\hline \multirow{2}{*}{ No. } & \multirow{2}{*}{ Model } & \multicolumn{2}{|c|}{ Akaike's Information Criterion } \\
\hline & & Perdesaan & Perkotaan \\
\hline (1) & (2) & (3) & (4) \\
\hline \multicolumn{4}{|c|}{ Semiparametrik } \\
\hline 1 & Cox PH & $8.488,92$ & $10.422,53$ \\
\hline \multicolumn{4}{|c|}{ Parametrik } \\
\hline 1 & Ekponensial & $3.654,98$ & $4.226,40$ \\
\hline 2 & Gompertz & $2.650,53$ & $3.062,18$ \\
\hline 3 & Weibull & $2.679,70$ & $3.074,89$ \\
\hline
\end{tabular}

Berdasarkan Tabel 2, Hasil perbandingan nilai AIC pemodelan ketahanan bersekolah diperdesaan dan perkotaan, distribusi Gompertz memilki nilai AIC terkecil. AIC distribusi Gompertz di daerah perdesaan sebesar 2.650,53 dan daerah perkotaan sebesar 3.062,18. Sehingga model terbaik yang digunakan untuk mengidentifikasi faktor yang mempengaruhi ketahanan bersekolah adalah model Gompertz PH yang bersifat parametrik, baik untuk daerah perdesaan maupun perkotaan.

\section{Pembentukan Model Ketahanan Bersekolah dengan Variabel Bebas}

Setalah melakukan pemilihan distribusi parametrik, selanjutnya dilakukan pemodelan dengan seluruh variabel bebas yang telah memenuhi asumsi PH dan membentuk model terbaik dengan metode backward elimination. Dari pemodelan model parametrik distribusi Gompertz yang sudah memenuhi asumsi PH daerah perdesaan maupun perkotaan, diperoleh model terbaik dengan AIC terkecil di daerah pedesaan sebesar 2.650,53 yang terdiri dari enam variabel bebas, yakni: bantuan KIP, jenis kelamin KRT, pendidikan KRT, lapangan usaha KRT, status kemiskinan dan status orangtua. Sementara untuk model perkotaan diperoleh model terbaik dengan AIC terkecil sebesar 3.058,43 yang terdiri dari tiga variabel bebas, yakni: pendidikan KRT, status kemiskinan dan status orangtua. Berikut adalah hasil pemodelan model parametrik distribusi Gompertz terbaik dearah perdesaan dan perkotaan :

Tabel 3. Hasil pemodelan terbaik dengan model parametrik distribusi Gompertz daerah perdesaan

\begin{tabular}{|c|c|c|c|c|}
\hline Variabel & Kategori & $\beta$ & Hazard Ratio & $P$-value \\
\hline (1) & (2) & (3) & (4) & (5) \\
\hline \multirow{2}{*}{ Bantuan KIP } & Menerima (ref) & & & \\
\hline & Tidak Menerima & 1,3101 & 3,6060 & $0,000 *$ \\
\hline \multirow{2}{*}{ JK KRT } & Laki-laki (ref) & & & \\
\hline & Perempuan & $-0,3579$ & 0,6991 & 0,100 \\
\hline \multirow{3}{*}{ Pendidikan KRT } & Tinggi (ref) & & & \\
\hline & Menengah & 0,7714 & 2,1627 & 0,006* \\
\hline & Dasar & 1,8266 & 6,2130 & $0,000 *$ \\
\hline \multirow{2}{*}{ Lapangan Usaha KRT } & Non-Pertanian (ref) & & & \\
\hline & Pertanian & 0,2186 & 1,2442 & $0,048^{*}$ \\
\hline \multirow{2}{*}{ Status Kemiskinan } & Tidak Miskin (ref) & & & \\
\hline & Miskin & 0,4858 & 1,6255 & $0,000 *$ \\
\hline \multirow{2}{*}{ Status Orang Tua } & Lengkap (ref) & & & \\
\hline & Tunggal & 0,4411 & 1,5545 & $0,020 *$ \\
\hline Intercept $\left(\beta_{0}\right)$ & & $-10,0627$ & & \\
\hline /gamma & & 0,5125 & & \\
\hline
\end{tabular}

Sumber: Susenas 2017, diolah

Keterangan: * = Siginfikan pada a 5 persen.

ref $=$ referensi 
Tabel 4. Hasil pemodelan terbaik dengan model parametrik distribusi Gompertz daerah perkotaan

\begin{tabular}{|c|c|c|c|c|}
\hline Variabel & Kategori & B & Hazard Ratio & $P$-value \\
\hline$(1)$ & $(2)$ & (3) & (4) & $(5)$ \\
\hline \multirow{3}{*}{ Pendidikan KRT } & Tinggi (ref) & & & \\
\hline & Menengah & 0,6367 & 1,8903 & 0,225 \\
\hline & Dasar & 1,5565 & 4,7423 & $0,002^{*}$ \\
\hline \multirow{2}{*}{ Status Kemiskinan } & Tidak Miskin (ref) & & & \\
\hline & Miskin & 0,6889 & 1,9915 & $0,000 *$ \\
\hline \multirow{2}{*}{ Status Orang Tua } & Lengkap (ref) & & & \\
\hline & Tunggal & 0,3522 & 1,4222 & $0,002^{*}$ \\
\hline Intercept $\left(\beta_{0}\right)$ & & $-8,3295$ & & \\
\hline /gamma & & 0,4968 & & \\
\hline
\end{tabular}

Sumber: Susenas 2017, diolah

Keterangan: $*$ S Siginfikan pada a 5 persen

ref $=$ referensi

\section{Pengujian Parameter}

Berdasarkan Tabel $\mathbf{3}$ dan Tabel 4, dapat dilihat hasil pemodelan model terbaik distribusi Gompertz untuk daerah perdesaan dan perkotaan. Selanjutnya, dilakukan uji secara simultan dan parsial untuk mengetahui pengaruh variabel bebas terhadap ketahanan bersekolah daerah perdesaan dan perkotaan. Untuk mengtahui pengaruh variabel bebas secara bersama-sama terhadap variabel terikat, maka dilakukan uji dengan menggunakan liklehood ratio test dengan tingkat signifikansi 5 persen. Hasil uji simultan daerah perdesaan diperoleh nilai likelihood ratio sebesar 254,45 dan $p$-value sebesar 0,000, dimana $p$-value $<0,05$, maka tolak H0 sehingga dapat disimpulkan bahwa minimal terdapat satu variabel bebas yang memepengaruhi ketahanan bersekolah di daerah perdesaan. Sementara itu hasil uji simultan didaerah perkotaan diperoleh nilai likelihood ratio sebesar 115,32 dan $p$-value sebesar 0,000, dimana $p$-value $<0,05$, maka tolak H0 sehingga dapat disimpulkan bahwa minimal terdapat satu variabel bebas yang memepengaruhi ketahanan bersekolah di daerah perkotaan.

Selanjutnya dilakukan uji parsial (Wald test) untuk mengetahui pengaruh masing-masing variabel bebas terhadap variabel terikat pada masing-masing model. Pengujian parsial pada penelitian ini menggunakan tingkat singifikasi 5 persen. Hasil pengujian parsial untuk daerah perdesaan dan perkotaan dapat dilihat pada tabel 3 dan 4. Pada daerah perdesaan terdapat lima variabel bebas yang signifikan, yakni: bantuan KIP, pendidikan KRT, lapangan usaha KRT, status kemiskinan dan status orangtua. Hal ini berarti dengan tingkat signifikansi lima persen, variabelvariabel bebas tersebut masing-masing mempengaruhi ketahanan bersekolah di daerah perdesaan. Sementara itu, untuk daerah perkotaan terdapat tiga variabel bebas yang signifikan yakni: pendidikan KRT, status kemiskinan dan status orangtua. Hal ini berarti dengan tingkat signifikansi lima persen, variabel-variabel bebas tersebut masing-masing mempengaruhi ketahanan bersekolah di daerah perkotaan.

Berdasarkan tabel 3 dan 4, dari serangkaian uji yang yang telah dilakukan, terbentuklah persamaan model paremetrik distribusi Gompertz terbaik yang dapat menggambarkan ketahanan bersekolah penduduk daerah perdesaan dan perkotaan usia 7-18 tahun di Provinsi Jawa Tengah Tahun 2017. Berikut adalah model untuk daerah perdesaan dan perkotaan:

$\hat{h}(t, x)=\exp (0,5125 t) \exp \left(-10,0627+1,3102\right.$ Bantuan $K I P^{*}-0,3579 J K K R T+$

0,7714 Pendidikan KRT ${ }^{*}$ Menengah $+1,8266$ Pendidikan $K R T^{*}{ }_{\text {Dasar }}+$

0,4858 Status Kemiskinan* + 0,4411 Status Orangtua*)Model Perdesaan 
Model Perkotaan

$$
\begin{aligned}
\hat{h}(t, x)=\exp (0,4968 t) \exp \left(-8,3295+0,6367 \text { Pendidikan } K R T_{\text {Menengah }}\right. \\
+1,5565 \text { Pendidikan } K R T^{*}{ }_{\text {Dasar }}+0,6889 \text { Status Kemiskinan }^{*} \\
\left.+0,3522 \text { Status Orangtua }{ }^{*}\right)
\end{aligned}
$$

Ket : * = signifakan pada a $(0,05)$

\section{Baseline Hazard}

Basline hazard yang digunakan dalam penelitian ini memilki bentuk Nilai /gamma merupakan penduga dari $\mathrm{Y}$. Berdsarkan model yang sudah terbentuk nilai /gamma untuk daerah perdesaan $(0,5152)$ dan perkotaan $(0,4968)$. Basline hazard yang terbentuk untuk daerah perdesaa dan perkotaan. Nilai $>0$ menunjukan bahwa hazard atau resiko penduduk usia 7-18 tahun untuk putus sekolah meningkat seiring waktu, baik untuk daerah perdesaan maupun perkotaan.

\section{Bantuan Kartu Indonesia Pintar (KIP)}

Kategori referensi pada variabel ini adalah menerima bantuan KIP. Di dearah perdesaan variabel lapangan bantuan KIP berpengaruh secara signifikan, sedangkan untuk daerah perkotaan tidak berpengaruh signifikan. Untuk daerah perdesaan nilai hazard ratio 3,6 artinya penduduk usia 7-18 tahun yang tidak menerima bantuan KIP beresiko putus sekolah 3,6 kali dibandingkan dengan penduduk usia 7-18 tahun yang merima bantuan KIP. Hasil ini sejalan dengan temuan Dakhyu (2011) dan Setyadharma (2018) yang mana tujuan beasiswa atau bantuan pendidikan adalah agar siswa bisa melanjutkan pendidikan yang lebih tinggi, terutama siswa yang berasal dari keluarga miskin atau kurang mampu.

\section{Pendidikan Kepala Rumah Tangga}

Kategori referensi pada variabel ini adalah pendidikan KRT dengan pendidikan tinggi. Di dearah perdesaan variabel pendidikan KRT berpengaruh secara signifikan untuk kategori pendidikan menengah dan dasar. Sedangkan untuk daerah perkotaan variabel pendidikan KRT berpengaruh secara signifikan untuk kategori pendidikan dasar. Untuk daerah perdesaan pada kategori pendidikan menengah nilai hazard ratio 2,16 artinya penduduk usia 7-18 tahun dengan tingkat pendidikan KRT pendidikan menengah beresiko putus sekolah 2,16 kali dibandingkan dengan penduduk usia 7-18 tahun yang tingkat pendidikan KRT pendidikan tinggi. Sementara itu, untuk kategori pendidikan dasar nilai hazard ratio 6,21 artinya penduduk usia 7-18 tahun dengan tingkat pendidikan KRT pendidikan dasar beresiko putus sekolah 6,21 kali dibandingkan dengan penduduk usia 7-18 tahun yang tingkat pendidikan KRT pendidikan tinggi. Untuk daerah perkotaan pada kategori pendidikan dasar nilai hazard ratio 4,74 artinya penduduk usia 7-18 tahun dengan tingkat pendidikan KRT pendidikan dasar beresiko putus sekolah 4,74 kali dibandingkan dengan penduduk usia 7-18 tahun yang tingkat pendidikan KRT pendidikan tinggi.

Hasil ini sejalan dengan temuan Wassahua (2016), Sudarwati (2009) dan Song, dkk (2012) yang mana anak yang berasal dari keluarga dengan tingkat pendidikan orang tua rendah cenderung untuk putus sekolah. Hal ini dikarenakan orantua yang tidak mengenyam pendidikan yang baik, sehingga hal ini berpengarauh pada kurangnya pemahaman dan pengetahuan tentang pentingnya pendidikan bagi anak.

\section{Lapangan Usaha Kepala Rumah Tangga}

Kategori referensi pada variabel ini adalah lapangan usaha KRT di sektor non-pertanian. Di dearah perdesaan variabel lapangan usaha KRT berpengaruh secara signifikan, sedangkan untuk daerah perkotaan tidak berpengaruh signifikan. Untuk daerah perdesaan pada kategori pertanian nilai hazard ratio 1,24 artinya penduduk usia 7-18 tahun dengan KRT yang bekerja disektor pertanian beresiko putus sekolah 1,24 kali dibandingkan dengan penduduk usia 7-18 tahun dengan KRT yang bekerja disektor non-pertanian. Hasil ini sejalan dengan temuan Bentri (2007) dan Purnawa (2006) yang mana anak yang bekerja disektor pertanian cenderung untuk putus sekolah. Hal ini dikarenakan umumnya orang tua yag bekerja di sektor pertanian tergolong kedalam keluarga kurang mampu sehingga resiko putus sekolahnya juga semakin besar. 


\section{Status Kemiskinan}

Kategori referensi pada variabel ini adalah status kemiskinan tidak miskin. Di daerah perdesaan dan perkotaan variabel status kemiskinan berpengaruh secara signifikan. Untuk daerah perdesaan nilai hazard ratio 1,62 artinya penduduk usia 7-18 tahun dengan status kemiskinan miskin beresiko putus sekolah 1,62 kali dibandingkan dengan penduduk usia 7-18 tahun yang tidak miskin. Sementara itu, untuk daerah perkotaan nilai hazard ratio 1,99 artinya penduduk usia 7-18 tahun dengan status kemiskinan miskin beresiko putus sekolah 1,99 kali dibandingkan dengan penduduk usia 7-18 tahun yang tidak miskin. Hasil ini sejalan dengan temuan Widyantari (2011) dan Sudarwati (2009) yang mana anak yang berasal dari keluarga kurang mampu atau miskin cenderung putus sekolah. Hal ini dikarenakan keadaan ekonomi keluarga yang kurang mendukung, tidak memiliki pekerjaan yang layak dan lebih mengutamakan untuk memenuhi kebutuhan sehari-hari daripada pendidikan. Sehingga banyak anak usia sekolah yang terhambat untuk melanjutkan pendidikan, bahkan kehilangan kesempatan mengikuti proses pendidikan.

\section{Status Orangtua}

Kategori referensi pada variabel ini adalah orangtua lengkap. Di daerah perdesaan dan perkotaan variabel status orangtua berpengaruh secara signifikan. Untuk daerah perdesaan nilai hazard ratio 1,55 artinya penduduk usia 7-18 tahun dengan status orangtua tunggal beresiko putus sekolah 1,55 kali dibandingkan dengan penduduk usia 7-18 tahun yang status orangtua lengkap. Sementara itu, untuk daerah perkotaan nilai hazard ratio 1,42 artinya penduduk usia 7-18 tahun dengan status orangtua tunggal beresiko putus sekolah 1,42 kali dibandingkan dengan penduduk usia 7-18 tahun yang status orangtua lengkap. Hasil ini sejalan dengan temuan Rumberger (1995), Pong dan Ju dalam Fan Yang (2018), menyatakan bahwa Anak yang tinggal dengan orangtua tunggal (single parent) memiliki kemungkinan putus sekolah lebih besar dibandingkan dengan orangtua lengkap.

\section{KESIMPULAN}

Persentase putus sekolah penduduk usia 7-18 tahun di Provinsi Jawa Tengah tahun 2017, baik untuk daerah perdesaan maupun perkotaan lebih banyak terjadi pada penduduk yang berjenis kelamin laki-laki, tidak menerima bantuan KIP, jenis kelamin KRT perempuan, jumlah anggota rumah tangga lebih dari 4, tingkat pendidikan KRT hanya sampai pendidikan dasar, lapangan usaha KRT di bidang pertanian, status kemiskinan miskin dan status orangtua tunggal.

Ketahanan bersekolah penduduk usia 7-18 tahun yang tinggal di daerah perdesaan lebih baik dari pada penduduk yang tinggal di daerah perkotaan di Provinsi Jawa Tengah tahun 2017. Terdapat beberapa variabel-variabel yang berpengaruh secara signifikan terhadap ketahanan bersekolah penduduk usia 7-18 tahun di Provinsi Jawa Tengah tahun 2017. Untuk daerah perdesaan terdapat lima variabel bebas yang signifikan, yakni: bantuan KIP, pendidikan KRT, lapangan usaha KRT, status kemiskinan dan status orangtua. Sementara itu, untuk daerah perkotaan terdapat tiga variabel bebas yang berpengaruh secara signifikan, yakni: pendidikan KRT, status kemiskinan dan status orangtua.

\section{DAFTAR PUSTAKA}

Badan Pusat Statistik. (2017). Pedoman Pencacah Susenas Maret 2017. Jakarta: Badan Pusat Statistik. Badan Pusat Statistik. (2017). Potret Pendidikan Indonesia Statistik Pendidikan Tahun 2017. Jakarta: Badan Pusat Statistik.

Badan Pusat Statistik. Sistem Informasi Rujukan Statisti (SIRUSA). Jakarta: Badan Pusat Statistik. Diakses pada tangal 26 Maret 2019 melalui https://sirusa.bps.go.id/sirusa/index.php/variabel/6191.

Badan Pusat Statistik. (2017). Survei Sosial Ekonomi Nasional 2017 Maret (KOR). Jakarta: Badan Pusat Statistik. Diakses pada tanggal 26 Maret 2019 melalui https://mikrodata.bps.go.id/mikrodata/index.php/catalog/814.

Badan Pusat Statistik. (2017). Statistik Pendidikan Provinsi Jawa Tengah Tahun 2017. Jakarta: Badan Pusat Statistik.

Dahlan, M. S (2013). Analisis Survival: Dasar-dasar Teori dan Aplikasi Program Stata. Jakarta: Sagung Seto. 
Gunawan, Ary H. (2010). Sosiologi Pendidikan Suatu Analisis Sosiologi tentang Pelbagai Problem Pendidikan. Jakarta: Rineka Cipta.

Hjartardottir, H. (2016). Surviving Calculus: A survival analysis of dropout from calculus at the University of Iceland. Iceland : University of Iceland.

Holmes, Jessica. (1999). Measuring the Determinants of School Completion in Pakistan: Analysis of Censoring and Selection bias. Educational Resources Information Center (ERIC), 1-65.

Hox, J. (2010). Multilevel Analysis: Techniques and Aplications. New Jersey: Lawrence Erlabaum associates, Inc.

Jordan, J. L., Kostandini, G., \& Mykerezi, E. (2012). Rural and urban high school dropout rates: Are they different? Journal of Research in Rural Education, 27(12), 1-21. Retrieved from http://jrre.psu.edu/articles/27-12.pdf.

Kementerian Pemberdayaan Perempuan dan Perlindungan Anak. (2018). Profil Anak Indonesia tahun 2018. Jakarta : Kementerian Pemberdayaan Perempuan dan Perlindungan Anak.

Kementrian Pendidikan dan Kebudayaan. (2015). Rencana Strategis Kementrian Pendidikan dan Kebudayaan Tahun 2015-2019. Jakarta : Kementrian Pendidikan dan Kebudayaan

Kleinbaum, D. G. dan Klein, M. (2005). Survival Analysis : A sels-Learning Text, Second Edition. New York : Springer.

Lee, E. T. dan Wang, J. W. (2003). Statistical Methods for Survival Data Analysis, Third Edition. Hoboken, New Jersey : John Wileys \& Sons, Inc.

Maunah, B. (2009). Ilmu Pendidikan. Yogyakarta: Teras.

Muniroh, Mumun Siti. (2011). Psikologi Keberlanjutan Sekolah Pekerja Anak di Sektor Batik. Jurnal Penelitian Vol.8, No.2.November 2011.

Peraturan Menteri Pendidikan dan Kebudayaan. (2016). Peraturan Menteri Pendidikan dan Kebudayaan No 19 Tahun 2016 tentang Program Indonesia Pintar. Mendikbud: Jakarta.

Pong, S. L dan Ju, D. B. (2000). The Effects of Change in Family Structure and Income on Dropping Out of Middle and High School. Journal of Family Issues, 21(2), 147-169.

Rumberger, W. R. (1995). Droping out of middle school: A Multilevel Analysis of Students and Schools. America Educational Research Journal.

Setyadharma, A. (2018). Government's Cash Transfers And School Dropout In Rural Areas. Journal of Economics and Policy, Jejak Vol 11 (2) (2018): 447-461.

Song, C, Dkk. (2012). Dropping Out of High School: The Effects of Family Structure and Family Transitions. Journal of Divorce \& Remarriage, 53(1), 18-33.

Sudarwati. (2009). Perbedaan Resiko Putus Sekolah Anak Usia 7-15 Tahun pada Tahun 1998 dan 2006 di Indonesia.[Tesis]. Depok: Universitas Indonesia.

Supriadie, D. (2009). Membangun Ketahanan Sekolah. Bandung: Universitas Pendidikan Indonesia.

RI (Republik Indonesia). (2003). Undang-undang Republik Indonesia Nomor 20 tahun 2003 tentang Sistem Pendidikan Nasional.

United Nations Development Programme. (2015). Indicators and Data Mapping to Measure Sustaineble Development Goals (SDGs) Targets. Jakarta: United Nations Development Programme.

Walpole E. R. (2015). Pengantar Statistika. Jakarta: PT. Gramedia Pustaka Utama

Yang, Fan. (2017). A competing risks survival analysis of high school dropout and graduation: a two-stage model specification approach. Amerika Serikat : University of Iowa. 